\title{
COMPARATIVE ANALYSIS OF FIRE-FIGHTER INTERVENTIONS IN THREE PROVINCES IN POLAND, BASED ON DATA FROM THREE COUNTIES
}

\author{
Lukasz Czyzewski ${ }^{1-3}$, Dawid Beczek ${ }^{4}$, Karol Tomaszewski ${ }^{4}$, Dariusz Daniluk ${ }^{4}$, Emilian Siemieniuk ${ }^{4}$ \\ ${ }^{1}$ Department of Nephrology Nursing, Medical University of Warsaw, Warsaw, Poland \\ ${ }^{2}$ Faculty of Health Sciences, Collegium Mazovia Innovative University, Siedlce, Poland \\ ${ }^{3}$ Department of Anaesthesiology, Cardinal Wyszynski National Institute of Cardiology, Warsaw, Poland \\ ${ }^{4}$ Student of Faculty of Health Sciences, Collegium Mazovia Innovative University, Siedlce. Poland
}

\begin{abstract}
INTRODUCTION: The speed of intervention of Fire Brigade units has a direct impact on the chance of saving people's lives and the effectiveness of rescue and fire-fighting operations. The aim of the research is to indicate the concentration of interventions and characteristics of events divided into the following: fire; local hazards; false alarms; time of arrival of the first fire brigade determined by distance; a comparison of the number of fire-fighters divided into groups of the Volunteer Fire Department (VFD) and State Fire Service (SFS); time of intervention; number of victims; and the need to support cooperating services i.e. police, medical rescue teams (MRT) and AMR Air Ambulance.
\end{abstract}

METHODS: The study was carried out on the basis of reports of events registered by the SFS on duty. Data concerned the period January-March 2017. The study included Siemiatycze county in Podlaskie Province, Łosice county in Mazovia Province and Łuków county in Lublin Province.

RESULTS: The frequency of events is higher in the countryside than in cities. The number of VFB in individual counties is similar with 119 in Łosice county and 129 in Łuków county with only 79 in Siemiatycze county, while the number of SFS hosts slightly differs in Łuków county $(n=131)$ from Łosice county $(n=76)$ and Siemiatycze county $(n=79)$, where this number is similar.

CONCLUSIONS: Our data indicates that: (1) SFS and VFB reaction time for interventions in our region does not differ from other data available in the literature; (2) this paper is of interest to workforce planners. We hope it provides important information to fire-fighters that should facilitate the maintenance of a successful and effective service.

KEY WORDS: State Fire Service, Volunteer Fire Department, fire-fighters, transport accessibility

Disaster Emerg Med J 2017; 2(4): 155-159

\section{INTRODUCTION}

Pursuant to the Law on the State Fire Service [1. art. 2 points 1-3], fire-fighting remits [State Fire Service (SFS) and Volunteer Fire Department (VFD)] include the identification of fire hazards and local threats, organizing and conducting rescue interventions (during the eradication of local hazards, fires and natural disasters). Local threats were defined in the law on fire protection as follows: events resulting from the development of civilization and the natural 
laws of nature that are not a fire or natural disaster, posing a threat to life, health, property or the environment, whose prevention or removal of effects do not require extraordinary measures [1].

The speed of intervention of Fire Brigade units has a direct impact on the chance of saving people's lives and the effectiveness of rescue and fire-fighting operations. During such events the following are of key importance: the time of departure and the time of arrival of the fire brigade unit to the site of the event. According to the standards in force in Poland, the location of SFS units should provide access to the site of an event in less than 8 minutes [2].

The aim of the research is to indicate the concentration of events, characteristics of events divided into: fire; local hazards; false alarms; time of arrival of the first fire brigade determined by distance; a comparison of the number of fire-fighters divided into groups of VFD and SFS; time of intervention; number of victims; and the need to support cooperating services i.e. police, medical rescue teams (MRT) and AMR Air Ambulance.

\section{MATERIAL AND METHODS}

The study was carried out on the basis of reports of events registered by the SFS on duty. Data concerned the period January-March 2017. The study included Siemiatycze county in Podlaskie Province, Łosice county in Mazovia Province and Łuków county in Lublin Province. The consent of the commanders of individual Fire and Rescue Units was obtained for conducting the study. The survey conformed to the principles outlined in the Declaration of Helsinki. All data were analyzed anonymously with no possibility of identifying individual patients.

\section{Description of the research area}

Siemiatycze county, whose seat is the city of Siemiatycze, is located in the south of Podlasie Province (Poland). It borders Belarus, and the provinces of Podlasie and Mazovia. The River Bug marks the southern border of the county. Siemiatycze county is inhabited by 45,538 people, which when placed in an area of $1459 \mathrm{~km}^{2}$, gives a population density of 31 persons $/ \mathrm{km}^{2}$. In terms of its administrative structure, Siemiatycze county is divided into 9 communes - 1 city commune, 1 town commune and 7 rural communes. In Siemiatycze county, there is 1 unit of the SFS and 62 units of the VFB, of which 15 are in the National Fire and Rescue System [3, 4].
Łosice county, whose seat is the city of Łosice, is located in the province of Mazovia. It is the easternmost county of Masovia province and is adjacent to the provinces of Podlasie and Lublin. In terms of its administrative structure, tosice county is divided into 6 communes, 1 of which is a town commune, the rest being rural communes. Łosice county is inhabited by 31,544 people, which when placed in an area of $772 \mathrm{~km}^{2}$, gives a population density of 41 persons $/ \mathrm{km}^{2}$. There is 1 SFS unit and 46 VFB units, of which 10 units are in the National Fire and Rescue System [5].

Łuków county, whose seat is the city of Łuków, is located in Lublin Province. It is the westernmost county in Lublin province and borders entirely with the province of Mazovia. In terms of its administrative structure, Łuków county is divided into 11 communes, of which 2 are town communes, the rest being rural communes. Łuków county is inhabited by 108,299 people, which when placed in an area of $1394 \mathrm{~km}^{2}$, gives a population density of 78 persons $/ \mathrm{km}^{2}$. There is $1 \mathrm{SFS}$ unit and 87 VFB units, of which 14 units are in the National Fire and Rescue System [6].

In Siemiatycze county, in the analyzed period, a total of 97 events were recorded, comprising 37 fires, 60 local threats and no false alarms. Events occurred 28 times in urban areas and 69 times in rural areas. Individual cooperating services participated in the incidents, namely: police -23 times, MRT - 20 times, AMR Air Ambulance - 4 times. There were 18 people injured and 1 death. The rescue and fire-fighting crews participating in the incidents were as follows: 78 - SFS, 73 - VFB and 2 - Factory Fire Service. The total number of rescuers participating in the events was SFS - 353 and VFB -344 .

In the area of Łosice county, there were 94 interventions with the participation of the fire brigade, including 5 false alarms, 33 fires and 56 local threats. Events occurred 16 times in urban areas and 78 times in rural areas, of which the average time of arrival of the first rescue unit was 8.29 minutes, the average distance being $5.20 \mathrm{~km}$. The total number of VFB was 119 and SFS - 76, while the number of firemen taking part in the VFB events was 592, and the number of firemen taking part in the SFS was 328. The average time of operation of the fire-fighters on the spot was $91.36 \mathrm{~min}$. Individual cooperating services that participated in the rescue and fire-fighting activities were as follows: 
police -30 times, MRT -15 times and AMR Air Ambulance - 1 time. During the period analyzed, 19 people were injured and 2 people died as a result of the incident.

In Łuków county in the analyzed period 140 events requiring the involvement of the fire brigade were recorded of which 91 were local threats, 44 fires and 5 false alarms. Events occurred 43 times in urban areas, 97 times in rural areas, of which the average time of arrival of the first rescue unit was 9.2 minutes, the average distance being $5.8 \mathrm{~km}$. In each case, an average of 3.4 paramedics attended from the SFS and 4.5 from the VFB while, altogether, 480 SFS rescuers and 627 VFB rescuers participated in dealing with 140 events. The average time of operation of the fire-fighters on the spot was 81.4 minutes. Individual cooperating services that participated in the rescue and fire-fighting activities were as follows: police - 87 times, MRT - 45 times, AMR Air Ambulance - 2 times. During the analyzed period, 31 people were injured and 2 people died.

\section{Statistical analysis}

Results concerning quantitative variables were presented as average values \pm standard deviation. Qualitative variables were presented as quantity (n) and percentage values of the whole group (\%) while proportions in groups were assessed with a Chi-squared test. In the comparative descriptions of interventions in the provinces of Mazovia. Lublin and Podlasie, the ANOVA test was used. Statistica 13.1 software (StatSoft Inc., Tulsa. OK) was used in the statistical analysis. $\mathrm{P}<0.05$ was adopted as the level of statistical significance.

\section{RESULTS}

Based on the results it was noted that the number of false alarms in both the county of Łosice and Łuków is the same $(n=5)$, while Siemiatycze county did not record any such alarms. The number of fires in comparable counties is similar, while the number of local threats in Łosice county $(n=56)$ and Siemiatycze county $(n=60)$ is almost the same and almost half that of Łuków county $(n=91)$. It was noticed that in the counties of Łosice, Łuków and Siemiatycze, the frequency of events is higher in the countryside than in cities. The number of VFB in individual counties is similar with 119 in Łosice county and 129 in Łuków county and only 79 in Siemiatycze county, while the number of SFS hosts slightly differs in Łuków county $(n=131)$ from Łosice county $(n=76)$ and Siemiatycze county $(n=79)$, where this number is similar.

The number of fire-fighters from the VFB participating in the described events is comparable in Łosice county $(n=592)$ and Łuków county $(n=629)$ while being half as much $(n=353)$ in Siemiatycze county. The number of fire-fighters from the SFS is slightly different and is almost half the size of that of the VFB in the following counties: Łosice $(n=328)$ and Łuków ( $n=480$ ). The number of injured persons is much greater than the number of deaths in each of the county while the number of people injured in Łuków county $(n=31)$ is much larger than in Łosice county $(n=19)$ and Siemiatycze county $(n=18)$, the number of deaths being almost the same. In Łuków county the police and MRT were called out more often to incidents than in Łosice and Siemiatycze counties. Moreover, the AMR Air Ambulance was called out only once in Łosice and Siemiatycze counties, but twice in Łuków county (Tab. 1).

\section{DISCUSSION}

A study conducted by Mazur et al. [7] presents an analysis of the distribution of selected features of local threats registered in the information from

\begin{tabular}{|c|c|c|c|c|}
\hline \multirow{2}{*}{ Variable } & \multicolumn{3}{|c|}{ Province } & \multirow{2}{*}{$\mathbf{P}$} \\
\hline & Masovia & Lublin & Podlasie & \\
\hline$n$ & 94 & 140 & 97 & \\
\hline Time of arrival [min] & $8.3 \pm 5.1$ & $9.2 \pm 7.3$ & $10.0 \pm 5.1$ & 0.153 \\
\hline Distance $[\mathrm{km}]$ & $5.2 \pm 4.7$ & $5.8 \pm 5.8$ & $4.5 \pm 4.1$ & 0.154 \\
\hline Number of fire-fighters OSP & $6 \pm 7$ & $5 \pm 4$ & $4 \pm 4$ & 0.047 \\
\hline Number of fire-fighters PSP & $4 \pm 3$ & $3 \pm 2$ & $4 \pm 3$ & 0.870 \\
\hline Order execution time [min] & $91.4 \pm 99.8$ & $81.4 \pm 56.8$ & No data & 0.335 \\
\hline
\end{tabular}


SFS events for the years 2007-2012. The analysis and evaluation were subjected in particular to the following: the total number of incidents, as well as wounded and fatalities. The analysis was carried out at a national level and broken down into subject classifications. Annual indicators of wounded and fatalities were prepared, as well as incidence rates of events in the six-year period of the study. The research results indicated that local hazards usually appear in the category of other objects (39\%), residential buildings (31\%) and means of transport (20\%). They report mortality rates of $25 \%, 22 \%$, $49 \%$ and wounded rates of $4 \%, 8 \%, 86 \%$, respectively. In the course of the six years analyzed, it was noticed that residential facilities recorded a steady increase in wounded and fatalities, while in transport the tendency was reversed.

In a study conducted by Guła et al. [8] "Rescue and medical interventions" presents an analysis of 117 interventions by the SFS based on the example of the actions of the Rescue and Fire Fighting Unit in Wieliczka, consisting mainly in providing medical assistance to the victims. It was demonstrated that in 56 cases, SFS rescuers were in place before MRT, while in 9 cases they operated under mass event conditions: hence they meticulously cooperated with MRT. After analyzing the nature of the calls and the scope of procedures performed on the spot, the activities of the SFS units as the first link and their role in the Polish rescue system were analyzed, taking into account the experience of other countries.

In a study conducted by Borowska-Stefańska et al. [9] entitled "Transport availability from Fire brigade units to buildings located in floodplains in the Zduńskowolski county", it was shown that there were a total of 514 buildings within the flood plains of the Zduńskowolski county. In the first stage, the number of buildings in within isochrones of 0-8 minutes and 8-15 minutes from the district/city headquarters of the SFS was analyzed. It was established that up to 41 buildings may be reached within 8 minutes, and up to 79 facilities within $8-15$ minutes. For the remaining $77 \%$ of the facilities located in the flood plains in the event of a flood, the first forces and resources should be provided through units of the VFB. As a result of the inclusion of VFB in the analyzes, it was found that up to 327 buildings could be reached within 8 minutes. In the event of a flood, it is possible for services from the VFB units to reach up to 73 buildings within 8-15 minutes. Analyzing both the travel time from the SFS municipal commands and from the VFB units, it should be stated that in the event of a flood in the area of Zduńskowolski county, access to all buildings located within the floodplain is ensured within 15 minutes. This is very important, because only then is there a possibility to take effective action, and more importantly, the possibility of providing effective assistance to the injured.

In conclusion, our data indicates that: (1) SFS and $V F B$ reaction time for interventions in our region does not differ from other data available in the literature; (2) this paper is of interest to workforce planners. We hope it provides important information to fire-fighters that should facilitate the maintenance of a successful and effective service.

\section{ACKNOWLEDGMENTS}

The authors are very grateful to commanders of Fire and Rescue Units for making their reports available.

Conflict of interest: The authors declare that they have no conflicts of interests. None of authors involved in this study have any financial relationship to declare.

Source of support: No sources of financial and material support to be declared.

Name of the department and institution at which the research was carried out: Faculty of Health Sciences, Collegium Mazovia Innovative University, Siedlce, Poland.

\section{REFERENCES}

1. Act of 24 August 1991 on fire protection (Journal of Laws of 1991 No. 81. item 351).

2. Regulation of the Minister of Internal Affairs and Administration of 18 February 2011 on detailed rules for the organization of the national rescue and fire-extinguishing system (Journal of Laws of 2012 No. 46. item 239).

3. http://www.polskawliczbach.pl/powiat_siemiatycki\# podstawowe-informacje (3.12.2017).

4. http://www.siemiatycze.straz.bialystok.pl/ksrg.html (3.12.2017).

5. http://www.polskawliczbach.pl/powiat_losicki\#podstawowe-informacje (3.12.2017).

6. http://www.starostwolukow.pl/panorama/stowarzyszenia_i_organizacje/osp (3.12.2017).

7. Mazur R, Marzec M. Assessment of Safety Level in Aspect of 20072012 Statistic. Local Emergencies. BiTP. 2013; 31: 49-58. 
8. Guła P, Smereka J, Godzik M. Medical and rescue interventions of the State Fire Brigades on the basis of actions of the Fire Brigade Unit in Wieliczka. www.elsevier.pl:8080/plik-artykulu/1590/Interwencjeratowniczo.pd (3.12.2017).
9. Borowska-Stefańska M. Transport accessibility from firefighters to objects located within flood hazard areas in the district of Zduńska Wola. http://dx.doi.org/10.18778/1643-0700.16.1 (3.12.2017). 